\title{
Growth and Fruit Yield of Okro as Influenced by Genotypes and Mulch in the Guinea Savannah Conditions of Ghana
}

\author{
Richard Yaw Agyare, ${ }^{1}$ Mashark Seidu Abdulai, ${ }^{1}$ Samuel Saaka Buah,, \\ Emmanuel Ayipio, ${ }^{1}$ Samuel Kwame Bonsu, ${ }^{1}$ and Regine Tchientche Kamga ${ }^{2}$ \\ ${ }^{1}$ CSIR-Savanna Agricultural Research Institute, P.O. Box TL 52, Tamale, Ghana \\ ${ }^{2}$ World Vegetable Center, West and Central Africa-Coastal Humid (WCA-CH) Regions, Liaison Office Cameroon, \\ P.O. Box 2008, Messa, Yaounde, Cameroon \\ Correspondence should be addressed to Richard Yaw Agyare; agyareyaw85@gmail.com
}

Received 4 August 2017; Accepted 10 October 2017; Published 7 November 2017

Academic Editor: Maria Serrano

Copyright (C) 2017 Richard Yaw Agyare et al. This is an open access article distributed under the Creative Commons Attribution License, which permits unrestricted use, distribution, and reproduction in any medium, provided the original work is properly cited.

\begin{abstract}
The experiment was carried out to assess the suitability of different mulch materials in enhancing the growth and fruit yield of okro. Ten okro genotypes were evaluated in a split plot design with 3 replications. Three treatments of mulch (black plastic, grass, and no mulch) represented the main plots with the genotypes as the subplots. The result indicated significant $(P<0.05)$ genotypic variability among the genotypes for all parameters except plant girth. However, genotype and mulch interaction was not significant. The genotype Sasilon had the tallest plants $(82.6 \mathrm{~cm})$ and the highest fruit yield under all mulch conditions while Koni had the widest fruits $(34.1 \mathrm{~mm})$ with TZ SMN 10-3 having the longest fruits $(16.11 \mathrm{~cm})$. Number of fruits per plant ranged from 30 to 11 with an average of 21 . Mulching significantly $(P<0.05)$ influenced all parameters except fruit width and mean fruit weight. Plastic mulched plots had the greatest heights while no mulching had the least. The highest average yield was obtained under plastic mulch (3.49 $\mathrm{t} / \mathrm{ha})$ which was $4.2 \%$ higher than grass $(3.34 \mathrm{t} / \mathrm{ha})$ and $11 \%$ higher than no mulch $(3.11 \mathrm{t} / \mathrm{ha})$. The study has shown that mulching with black plastic or grass ensures vigorous growth and improves the fruit yield of okro.
\end{abstract}

\section{Introduction}

Okro (Abelmoschus esculentus (L.) Moench) belongs to the plant family Malvaceae and is the most common and widely cultivated crop within this family. It is an economically important vegetable crop cultivated in the tropics and subtropics of the world [1]. Okro is an important vegetable crop cultivated for its fresh immature fruits and sometimes young tender leaves. The immature fruits contain appreciable levels of vitamins and minerals and essential fatty acids such as linoleic acid [2]. It is an affordable source of dietary fibre, protein, and carbohydrates and constitutes a major component of many Ghanaian dishes: soups, stews, and salads. The consistency of many soups and sauces can be increased by adding the extract obtained from boiling the immature fruits. Okro has many medicinal properties and the mucilage has been used as a plasma replacement [3].

Okro production in the rainy and dry seasons (along river banks) serves as a source of employment for many people in Ghana. However, the cultivation of the crop is affected by many biotic and abiotic factors such as pests and diseases, low soil fertility, lack of improved seeds, and climate change. Climate change and its concomitant environmental stress will consequently reduce crop productivity especially in developing countries where crop production is mainly rainfed [4]. Intermittent or unpredictable drought and high temperatures during the growing season are important environmental challenges affecting crop productivity and food security worldwide [5].

Water availability is expected to be sensitive to climate change and severe water-stress conditions will affect crop productivity, particularly that of vegetables which generally consist of more than $90 \%$ water [6]. Reduced precipitation, in combination with elevated temperatures, could cause reduction of irrigation water availability and increased evapotranspiration, leading to severe crop waterstress conditions which reduces flower set and increases the rate of floral abscission. Evapotranspiration as influenced 
by high temperatures has been found to be a major factor contributing to declining yields of vegetable crops under irrigated conditions in Ghana [7]. Emphasis should therefore be on developing production systems for improved water use that are adaptable to the hot and dry conditions of northern Ghana. Earlier studies have indicated that cropping systems that utilize different degrees of soil cover reduce soil evaporation water loss and enhance crop water productivity $[8,9]$. The use of mulches has been found to cause $34-50 \%$ reduction in soil water evaporation compared with bare soil [10].

Mulch is any material derived from either organic or inorganic sources placed on the surface of the soil as a protective cover. Different types of mulch materials have been used to conserve moisture to enhance the growth and yield of several crops such as groundnut, soybean, sesame, and sunflower [1114]. Mulching helps to conserve soil moisture, moderate soil temperature, and prevent soil runoff and erosion [15]. The protective cover of mulches serves as a barrier and prevents direct contact between fruits and the soil. Mulching with black plastic or opaque materials prevents sunlight from reaching the soil surface which reduces weed growth and promotes soil warming and early crop establishment [16]. Mulching with coloured plastic has been found to prevent insect and disease damage on several crops [17]. The use of organic materials as mulch adds nutrients to the soil as they decompose and enhance crop growth and yields [16]. It also improves the physical, chemical, and biological properties of the soil. Although the importance of mulching cannot be overemphasized, however, there is very little information on the influence of mulch materials on okro production in the Guinea Savannah agroecological zone of northern Ghana where rainfall is unevenly distributed. There is therefore the need to assess the suitability of different mulch materials in enhancing the growth and yield of okro for intensive production. This study was carried out to assess the effect of different mulch materials on the growth and fruit yield of okro genotypes in northern Ghana.

\section{Materials and Methods}

2.1. Study Area. The experiment was conducted during the 2014 cropping season at the research field of the Savanna Agricultural Research Institute (SARI), Nyankpala in the Guinea Savannah zone of Ghana (N 09 $23^{\prime} 21.4^{\prime \prime}$, $\left.\mathrm{W} 001^{\circ} 00^{\prime} 13 \cdot 4^{\prime \prime}\right)$. The study area is characterized by a monomodal rainfall with an average annual rainfall of about 800 to $1200 \mathrm{~mm} \cdot \mathrm{yr}^{-1}$ which peaks between August and September and ends in October. The soils belong to the Kumayili series and are commonly classified as Ferric Luvisols. Table 1 describes some physical and chemical properties of the study site at a depth of $0-15 \mathrm{~cm}$.

2.2. Experimental Design and Treatments. The experiment was conducted in a split plot design with three replications. Three treatments of mulch (black plastic, grass mulch, and no mulch) represented the main plots with the 10 okro genotypes as the subplots. The land was ploughed with a disc-plough
TABLE 1: Soil physical and chemical properties of the study site.

\begin{tabular}{lc}
\hline Soil physical and chemical properties & \\
\hline Sand $(\%)$ & 59.84 \\
Silt $(\%)$ & 25.84 \\
Clay $(\%)$ & 14.32 \\
Soil pH $\left(1: 2.5 \mathrm{H}_{2} \mathrm{O}\right)$ & 6.61 \\
Organic carbon $(\%)$ & 0.27 \\
Available P $(\mathrm{mg} / \mathrm{kg})$ & 8.64 \\
$\mathrm{~K}+(\mathrm{mg} / \mathrm{kg})$ & 178.00 \\
Total nitrogen $(\%)$ & 0.03 \\
$\mathrm{Ca}(\mathrm{Cmol}(+) / \mathrm{Kg})$ & 3.72 \\
$\mathrm{Mg}(\mathrm{Cmol}(+) / \mathrm{Kg})$ & 1.60 \\
\hline
\end{tabular}

and ridges were manually prepared with traditional hoes. The black plastic (thickness $1.25 \mathrm{~mm}$ ) was used to cover the experimental plots before planting. Planting holes were made on the plastic mulch for planting the seed. The grass (straw) mulch was applied to the plots two weeks after seedling emergence at a rate of $4 \mathrm{t} / \mathrm{ha}$. The okro genotypes evaluated were Koni, Sasilon, ML OK 10, ML OK 16, ML OK 35, ML OK 37, TZ SMN 10-3, TZ SMN 86, TZ SMN 98, and Ex Makutopora. Okro seeds were soaked in water overnight before they were planted at spacing of $0.75 \mathrm{~m}$ between ridges and $0.50 \mathrm{~m}$ between plants. The plants were thinned to two plants per hill at two weeks after emergence. Each plot consisted of 4 rows measuring $3 \mathrm{~m}$ long and $3 \mathrm{~m}$ wide. Agronomic practices such as fertilizer application, insect pest, and diseases control were carried out appropriately to ensure good crop establishment.

2.3. Data Collection and Analysis. Agronomic data were collected on plant height $(\mathrm{cm})$, plant girth $(\mathrm{mm})$, fruit length $(\mathrm{cm})$, fruit width $(\mathrm{mm})$, fruit number per plot, number of fruits/plant, mean fruit weight, and fruit yield ( $t / h a)$. The measurements were taken on 4 tagged plants that were randomly selected from the two middle rows. The data were analysed using GenStat statistical package version 12.0 [18]. Multiple linear regression analysis was performed with $\mathrm{R}$ (version 3.2.3) software package [19] to develop a model for predicting the fruit yield of okro. A model consisting of three predictor variables (namely, shoot size index (SSI), fruit size index (FSI), and fruit number per plant) was first fitted to the data. Shoot size index and fruit size index are derived variables that were computed from plant height and plant girth, and fruit length and fruit width, respectively, to eliminate multicollinearity in the variables. Upon fitting the first model which consisted of three predictor variables, the regression coefficient for fruit size index was found not to be significantly different from zero $(P<0.05)$; hence it was eliminated from the first model to produce a reduced model that had only two predictor variables using a backward selection procedure.

$$
\begin{aligned}
& \text { Full model fitted: } \text { Yld }_{\mathrm{t} / \mathrm{ha}} \\
& \quad=\beta_{0}+\beta_{1} X_{\mathrm{SSI}}+\beta_{2} X_{\mathrm{FSI}}+\beta_{3} X_{\text {FrtNo_P }}+\varepsilon
\end{aligned}
$$


TABLE 2: Mean square values and significant levels for parameters measured.

\begin{tabular}{|c|c|c|c|c|c|c|c|c|c|}
\hline Source of variation & DF & PG & $\mathrm{PH}$ & FL & FW & FN & NFP & MFW & FY \\
\hline Replication & 2 & $23.83^{* * *}$ & $818.60 \mathrm{NS}$ & $10.94^{* *}$ & $32.07^{* * *}$ & $1450.80^{* * *}$ & $90.68^{* * *}$ & $33.83 \mathrm{NS}$ & $1.19^{* *}$ \\
\hline Genotype & 9 & $2.66 \mathrm{NS}$ & $1118.90^{* * *}$ & $38.58^{* * *}$ & $184.14^{* * *}$ & $4449.00^{* * *}$ & $278.06^{* * *}$ & $910.94^{* * *}$ & $25.86^{* * *}$ \\
\hline Mulch & 2 & $516.26^{* * *}$ & $13121.80^{* * *}$ & $22.13^{* * *}$ & $0.65 \mathrm{NS}$ & $1900.70^{* * *}$ & $118.80^{* * *}$ & $38.68 \mathrm{NS}$ & $1.13^{* *}$ \\
\hline Genotype $\times$ mulch & 18 & $1.78 \mathrm{NS}$ & $350.50 \mathrm{NS}$ & $0.53 \mathrm{NS}$ & $2.17 \mathrm{NS}$ & $84.70 \mathrm{NS}$ & $5.29 \mathrm{NS}$ & $18.38 \mathrm{NS}$ & $0.19 \mathrm{NS}$ \\
\hline Residual & 58 & 3.72 & 297.90 & 1.96 & 2.30 & 121.30 & 7.58 & 25.58 & 0.18 \\
\hline CV (\%) & & 12.50 & 26.00 & 11.50 & 6.00 & 13.00 & 13.00 & 14.80 & 13.00 \\
\hline
\end{tabular}

${ }^{*, * * * * * *}$ Significance at $P<0.05, P<0.01$, and $P<0.001$, respectively; NS = not significant $(P>0.05)$; DF = degree of freedom; $\mathrm{PG}=$ plant girth; $\mathrm{PH}=$ plant height; FL = fruit length; FW = fruit width; FN = fruit number; NFP = number of fruits/plant; MFW = mean fruit weight; FY = fruit yield.

TABLE 3: Growth and yield characteristics of okro genotypes evaluated under different mulch materials.

\begin{tabular}{|c|c|c|c|c|c|c|c|c|}
\hline Parameter & $\begin{array}{c}\text { Plant girth } \\
(\mathrm{mm})\end{array}$ & $\begin{array}{l}\text { Plant height } \\
(\mathrm{cm})\end{array}$ & $\begin{array}{l}\text { Fruit length } \\
(\mathrm{cm})\end{array}$ & $\begin{array}{c}\text { Fruit width } \\
(\mathrm{mm})\end{array}$ & Fruit number & $\begin{array}{l}\text { Number of } \\
\text { fruits/plant }\end{array}$ & $\begin{array}{l}\text { Mean fruit } \\
\text { weight }(\mathrm{g})\end{array}$ & $\begin{array}{c}\text { Fruit yield } \\
(\mathrm{t} / \mathrm{ha})\end{array}$ \\
\hline \multicolumn{9}{|l|}{ Mulch } \\
\hline Black plastic & $20.25 \mathrm{a}$ & $90.40 \mathrm{a}$ & $12.90 \mathrm{a}$ & $24.99 a$ & $92.00 \mathrm{a}$ & $23.00 \mathrm{a}$ & $32.99 a$ & $3.49 \mathrm{a}$ \\
\hline Grass & $13.15 b$ & $57.10 \mathrm{~b}$ & $12.41 \mathrm{a}$ & $25.28 \mathrm{a}$ & $85.00 \mathrm{~b}$ & $21.00 \mathrm{~b}$ & $34.13 a$ & $3.34 \mathrm{a}$ \\
\hline Bare (no mulch) & $12.98 \mathrm{~b}$ & $51.90 \mathrm{~b}$ & $11.23 b$ & $25.19 a$ & $77.00 \mathrm{c}$ & $19.00 \mathrm{c}$ & $35.26 \mathrm{a}$ & $3.11 \mathrm{~b}$ \\
\hline \multicolumn{9}{|l|}{ Genotype } \\
\hline Ex Makutopora & $15.42 \mathrm{a}$ & $69.50 \mathrm{abc}$ & $10.98 \mathrm{~d}$ & $24.29 \mathrm{~d}$ & $118.00 \mathrm{a}$ & $30.00 \mathrm{a}$ & $36.66 c$ & $4.80 \mathrm{~b}$ \\
\hline Koni & $15.22 \mathrm{a}$ & $79.10 \mathrm{a}$ & $10.05 \mathrm{~d}$ & $34.10 \mathrm{a}$ & $94.00 \mathrm{~b}$ & $24.00 \mathrm{~b}$ & $42.12 b$ & $4.43 \mathrm{~b}$ \\
\hline ML OK 10 & $16.09 \mathrm{a}$ & $69.10 \mathrm{abc}$ & $10.38 \mathrm{~d}$ & $25.60 \mathrm{~d}$ & $44.00 \mathrm{f}$ & $11.00 \mathrm{f}$ & 30.10def & $1.45 \mathrm{~g}$ \\
\hline ML OK 16 & $16.15 \mathrm{a}$ & $57.40 \mathrm{bcd}$ & $14.76 \mathrm{~b}$ & $21.29 \mathrm{e}$ & $94.00 \mathrm{~b}$ & $23.00 \mathrm{~b}$ & $26.06 f g$ & $2.74 \mathrm{~d}$ \\
\hline ML OK 35 & $14.99 a$ & $46.40 \mathrm{~d}$ & $12.47 \mathrm{c}$ & $22.50 \mathrm{e}$ & 70.00de & $18.00 \mathrm{de}$ & $24.24 \mathrm{~g}$ & $1.88 \mathrm{f}$ \\
\hline ML OK 37 & $15.76 \mathrm{a}$ & $72.20 \mathrm{ab}$ & $10.09 \mathrm{~d}$ & $31.15 b$ & $76.00 \mathrm{~cd}$ & $19.00 \mathrm{~cd}$ & $32.03 \mathrm{cde}$ & $2.71 \mathrm{~d}$ \\
\hline Sasilon & $14.44 \mathrm{a}$ & $82.60 \mathrm{a}$ & $13.08 \mathrm{c}$ & $27.82 \mathrm{c}$ & $113.00 \mathrm{a}$ & $28.00 \mathrm{a}$ & $58.63 \mathrm{a}$ & $7.12 \mathrm{a}$ \\
\hline TZ SMN 10-3 & $16.00 \mathrm{a}$ & $71.20 \mathrm{abc}$ & $16.11 \mathrm{a}$ & $21.59 \mathrm{e}$ & $65.00 \mathrm{e}$ & $16.00 \mathrm{e}$ & $30.75 \mathrm{def}$ & $2.25 \mathrm{ef}$ \\
\hline TZ SMN 86 & $15.23 \mathrm{a}$ & $55.40 \mathrm{~cd}$ & $10.97 \mathrm{~d}$ & $21.25 \mathrm{e}$ & $88.00 \mathrm{~b}$ & $22.00 \mathrm{~b}$ & $33.20 \mathrm{~cd}$ & $3.19 c$ \\
\hline TZ SMN 98 & $15.29 \mathrm{a}$ & $62.00 \mathrm{bcd}$ & $12.89 \mathrm{c}$ & $21.94 \mathrm{e}$ & $84.00 \mathrm{bc}$ & $21.00 \mathrm{bc}$ & $27.45 \mathrm{efg}$ & $2.55 \mathrm{de}$ \\
\hline
\end{tabular}

Means followed by the same letter within each column indicate no significant difference between treatments by Duncan's multiple range tests $(P<0.05)$.

Reduced model fitted: Yld $_{\mathrm{t} / \mathrm{ha}}$

$$
=\beta_{0}+\beta_{1} X_{\mathrm{SSI}}+\beta_{2} X_{\text {FrtNo_P }}+\varepsilon
$$

where $\beta_{0}$ is intercept, $\beta_{1}-\beta_{3}$ are regression coefficients or slopes for the three predictor variables (SSI, FSI, and FrtNo_P), $\varepsilon$ is residual or error term, $\mathrm{Yld}_{\mathrm{t} / \mathrm{ha}}$ is yield $(\mathrm{t} / \mathrm{ha})$, SSI is shoot size index (ratio of mean plant height to mean plant girth), FSI is fruit size index (ratio of fruit length to fruit width), and FrtNo_P = fruit number per plant.

\section{Results and Discussion}

3.1. Influence of Mulch on Growth and Yield Characteristics of Okro. The results indicated that all parameters measured, namely, plant girth, plant height, fruit length, fruit number, number of fruits/plant, and fruit yield, were significantly $(P<0.05)$ influenced by mulch except fruit width and mean fruit weight. However, genotypes and mulch interaction was not significant for any parameter (Table 2). Okro genotypes grown under black plastic mulch had the widest plant girth (20.25 mm) which was significantly different from plants grown under grass mulch $(13.15 \mathrm{~mm})$ and bare soil $(12.98 \mathrm{~mm})$ (Table 3$)$. The highest plant height $(90.40 \mathrm{~cm})$ recorded when plants were grown under black plastic mulch varied significantly from plants grown under grass mulch and bare soil with mean heights of $57.10 \mathrm{~cm}$ and $51.90 \mathrm{~cm}$, respectively. Fruit length was influenced by mulching with black plastic or grass, which significantly differed from no mulching. However, mulching did not influence fruit width. Fruit number and number of fruits per plant, respectively, differed among the mulch materials with the highest values observed when plants were grown under black plastic (92 and 23) followed by grass mulch ( 85 and 21) and bare soil (77 and 19). This result is comparable to report by Nkansah et al. [20] who indicated that application of mulch material significantly influenced fruit number per plant in tomato as compared to no mulching. Mean fruit weight was not significantly affected by mulching. The highest fruit yield was obtained under black plastic mulch (3.49t/ha) which was $4.2 \%$ higher than grass mulch (3.34 t/ha) and $11 \%$ higher than no mulch (3.11t/ha). This observation corroborates earlier work by Pandita and Singh [21] who recorded the 
TABLE 4: Pearson correlation analysis for eight traits obtained from 10 okro genotypes under three mulch treatments.

\begin{tabular}{|c|c|c|c|c|c|c|c|}
\hline SSI & & & & & & & -0.32 \\
\hline Yld_tha & & & & & & $0.63^{* * *}$ & -0.26 \\
\hline FrtNo_P & & & & & $0.82^{* * *}$ & $0.36^{*}$ & -0.04 \\
\hline FrtW & & & & 0.15 & $0.44^{*}$ & $0.53^{* *}$ & $-0.8^{* * *}$ \\
\hline FrtL & & & $-0.54^{* *}$ & 0.07 & -0.02 & -0.06 & $-0.89^{* * *}$ \\
\hline MPH & & 0.15 & 0.33 & 0.34 & $0.4^{*}$ & $0.64^{* * *}$ & -0.11 \\
\hline \multirow[t]{2}{*}{ MPG } & $0.77^{* * *}$ & 0.29 & -0.03 & 0.16 & 0.01 & 0.06 & 0.18 \\
\hline & MPH & FrtL & FrtW & FrtNo_P & Yld_tha & SSI & FSI \\
\hline
\end{tabular}

A correlation analysis for eight traits obtained from 10 okro genotypes under three mulch treatments. MPG = mean plant girth; MPH = mean plant height; $\mathrm{FrtL}=$ mean fruit length; FrtW = mean fruit width; FrtNo_P = fruit number per plant; Yld_tha $=$ fruit yield $(\mathrm{t} / \mathrm{ha}) ; \mathrm{SSI}=$ shoot size index; FSI = fruit size index; ${ }^{* * *}$ significant at $0.1 \% ;{ }^{* *}$ significant at $1 \% ;{ }^{*}$ significant at $5 \%$.

highest yields of okro and eggplant cultivars when they were mulched with plastic and grass mulches as compared with no mulch. The findings from the present study could be attributed to prolonged availability of soil moisture for crop growth during intermittent drought periods observed in the growing season. Mulching also suppressed weed growth and competition for limited available resources such as nutrients and water. This result is in agreement with Lamont [22] who reported that mulching enhanced soil hydrothermal regime and improved vegetative growth and fruit yield of tomato plants as compared to bare soil. Teame et al. [9] also observed that mulching significantly improved soil moisture content and influenced grain filling in sesame as compared to no mulching. The mulches protected the soil from the direct impact of rains, drying winds, and heat which compact the soil. Moisture stress during periods of intermittent drought was not experienced in the mulched plots which might have accounted for the improved performance of the okro genotypes.

3.2. Genotypic Variability among Okro Genotypes. The results indicated significant $(P<0.05)$ genotypic variability among the okro genotypes for the parameters measured except plant girth (Table 3). The highest plant height was obtained by Sasilon $(82.60 \mathrm{~cm})$ with the least height obtained by ML OK $35(46.40 \mathrm{~cm})$. Fruit length varied from $16.11 \mathrm{~cm}$ (TZ SMN 103) to $10.05 \mathrm{~cm}$ (Koni) with a mean of $12.18 \mathrm{~cm}$. Koni had the widest fruits $(34.10 \mathrm{~cm})$ with TZ SMN $86(21.25 \mathrm{~cm})$ obtaining the least fruit width. The highest fruit number was obtained by genotype Ex Makutopora (118 fruits) with TZ SMN 103 (65 fruits) obtaining the least fruit number. Mean fruit weight ranged from $58.63 \mathrm{~g}$ (Sasilon) to $24.24 \mathrm{~g}$ (ML OK 35) with a mean of $34.12 \mathrm{~g}$. Sasilon ( $7.12 \mathrm{t} / \mathrm{ha}$ ) had the highest average fruit yield with the least yield obtained by ML OK 35 $(1.88 \mathrm{t} / \mathrm{ha})$. Although the performance of the okro genotypes did not vary among the mulches, most of the parameters observed were found highest under black plastic mulch. This is in agreement with Vetrano et al. [23] who obtained the best performance of melon genotypes under polyethylene mulched plots.

3.3. Correlation Analysis. Correlation coefficients of parameters measured are presented in Table 4. Mean plant girth showed highly significant positive association $(r=0.77)$ with mean plant height but was however not significantly associated with the other parameters. Plant height possessed significant positive correlation $(r=0.40)$ with fruit yield. Fruit length had highly significant positive association with fruit size index (FSI) but significant negative correlation $(r=$ $-0.54)$ with fruit width. Fruit width had significant positive associations ( $r=0.44$ and 0.53 ) with fruit yield and SSI but had significant negative association with FSI. Fruit number per plant showed highly significant positive associations $(r=$ 0.82 and $r=0.36$ ) with fruit yield and SSI. Fruit yield showed highly significant positive correlations $(r=0.63)$ with SSI. Agyare et al. [24] found significant positive associations $(r=$ 0.51 and $r=0.71$ ) between plant height and plant girth and fruit yield and fruit width, respectively, in pepper. These traits can be used as indicators for selecting okro genotypes with desirable attributes especially fruit yield.

3.4. Multiple Linear Regression Analysis. Multiple linear regression analysis revealed that the full model was highly significant (F-statistic: 37.90) with the three predictor variables explaining 79\% (adjusted $R$-squared $=0.79$ ) of the variability in fruit yield of okro (Table 5). The regression coefficients for fruit number per plant $(0.21)$ and shoot size index $(0.53)$ were significantly different from zero $(P<0.01)$. The regression coefficient of fruit size index was however not significant $(P>0.05)$ and was eliminated from the model. The reduced model shows that the two predictor variables retained in the model explained $78 \%$ of the variability in the fruit yield of okro. The reduced model was preferred over the full model since its adjusted $R$-square was comparable to that of the full model and it is simple to use because of the low number of predictor variables in the model. The reduced model shows that increasing the fruit number per plant by one unit would result in an increase of $0.20 \mathrm{t} / \mathrm{ha}$ of okro fruit yield, while holding the shoot size index constant. Similarly, when the shoot size index increases by one unit, the fruit yield is predicted to increase by $0.61 \mathrm{t} / \mathrm{ha}$, while holding the fruit number per plant constant. This model has revealed that fruit number per plant and shoot size index could be a useful tool in predicting the fruit yield of okro genotypes. Future breeding programs aimed at okro yield improvement could be focused on improving the shoot size index and fruit number per plant. 
TABLE 5: Summary of regression coefficients for predictor variables and other parameters.

\begin{tabular}{|c|c|c|c|c|c|c|c|c|}
\hline \multirow{2}{*}{ Model Parameters } & \multicolumn{4}{|c|}{ Full model } & \multicolumn{4}{|c|}{ Reduced model } \\
\hline & Est & SE & $t$ value & $\operatorname{Pr}(>|t|)$ & Est & SE & $t$ value & $\operatorname{Pr}(>|t|)$ \\
\hline Intercept & -2.59 & 0.99 & -2.63 & $0.01408^{*}$ & -3.64 & 0.72 & -5.02 & $<0.001^{* * *}$ \\
\hline Fruit number per plant (FrtNo_P) & 0.21 & 0.03 & 7.94 & $<0.001^{* * *}$ & 0.20 & 0.03 & 7.66 & $<0.001^{* * *}$ \\
\hline Shoot size index (SSI) & 0.53 & 0.16 & 3.32 & $0.00269^{* *}$ & 0.61 & 0.15 & 3.95 & $<0.001^{* * *}$ \\
\hline Fruit size index (FSI) & -0.15 & 0.10 & -1.52 & $0.14051 \mathrm{NS}$ & & & & \\
\hline$R$-squared & 0.81 & & & & 0.80 & & & \\
\hline Adjusted $R$-squared & 0.79 & & & & 0.78 & & & \\
\hline$F$-statistic $(P<0.001)$ & \multicolumn{4}{|c|}{37.90 on $3, \mathrm{DF}=26$} & \multicolumn{4}{|c|}{53.11 on $2, \mathrm{DF}=27$} \\
\hline
\end{tabular}

$*, * *, * *$ Significant at $0.05,0.01$, and 0.001 , respectively. NS = not significant; Est = estimate (regression coefficient); SE = standard error.

\section{Conclusion}

Mulching resulted in better growth and yield of the different okro genotypes compared with the bare soil. Significant genotypic variability was observed among the okro genotypes for most of the parameters studied particularly fruit yield. Genotype and mulch interaction was not significant for any parameter suggesting that the performance of genotypes will not be affected irrespective of the type of mulch materials used. Plastic mulch enhanced the growth and yield of okro better than grass mulch as well as no mulching. Correlation analysis indicated that plant height and fruit width had significant positive association with fruit yield. A reduced fitted linear regression model revealed that $78 \%$ of the variability in fruit yield of okro was explained by fruit number per plant and shoot size index. Future fruit yield improvement programs could therefore be centered on improving fruit number per plant or the shoot size index of okro.

\section{Conflicts of Interest}

The authors declare that no conflicts of interest exist.

\section{Acknowledgments}

This study was supported in part by a commissioned project granted to The World Vegetable Center by CORAF/ WECARD (Grant no. CW/CP/03/PCN/NSC/02/2012 AVRDC 10000224) and funded through the World Bank by a Multi Donor Trust Fund composed of the European Union and the Canadian International Development Agency. The authors thank management and staff of CSIR-SARI for their support and useful critique. AVRDC is appreciated for providing seeds of the okro genotypes. Special thanks are due to Dr. Alexander Wireko Kena for helping with data analysis.

\section{References}

[1] A. Naveed, A. A. Khan, and I. A. Khan, "Generation mean analysis of water stress tolerance in okro (Abelmoschus esculentus L.)," Pakistan Journal of Botany, vol. 41, pp. 195-205, 2009.

[2] H. F. Gemede, N. Ratta, G. D. Haki, and Z. B. W. F. Ashagrie, "Nutritional quality and health benefits of Okro (Abelmoschus esculentus): A Review," Global Journal of Medical Research, vol. 5, pp. 28-37, 2014.
[3] R. P. Maramag, "Diuretic potential of Capsicum frutescens L., Corchorus oliturius L., and Abelmoschus esculentus L," Asian Journal of Natural and Applied Sciences, vol. 2, no. 1, pp. 60-69, 2013.

[4] E. A. Bray, J. Bailey-Serres, and E. Weretilnyk, "Responses to abiotic stresses," in Biochemistry and molecular biology of plants. ASPP, W. Gruissem, B. Buchannan, and R. Jones, Eds., pp. 11581249, MD, Rockville, 2000.

[5] FAO., "The state of the worlds land and water resources for food and agriculture (SOLAW) - Managing systems at risk," Food and Agriculture Organization of the United Nations, Rome and Earthscan, London, pp. 120-123, 2011.

[6] AVRDC., "Vegetable Production Training Manual". Asian Vegetable Research and Training Center, Shanhua, Taiwan," p. 447, 1990.

[7] P. B. Tanzubil, F. O. Annor-Nyarko, B. Aligebam, and I. Y. Baba, "Update on diagnosis of pest and disease problems in the Upper East Region (U.E.R.) of Ghana-2003/2004," in A Report on the "Tomato Disease Complex" Presented to the Ministry of Food and Agriculture, UER at a Stakeholders Meeting, Bolgatanga, Ghana, March 2004.

[8] D. Raes, P. Steduto, T. C. Hsiao, and E. Fereres, "Aquacrop-The FAO crop model to simulate yield response to water: II. main algorithms and software description," Agronomy Journal, vol. 101, no. 3, pp. 438-447, 2009.

[9] G. Teame, A. Tsegay, and B. Abrha, "Effect of Organic Mulching on Soil Moisture, Yield, and Yield Contributing Components of Sesame (Sesamum indicum L.)," International Journal of Agronomy, vol. 2017, pp. 1-6, 2017.

[10] J. L. Hatfield, T. J. Sauer, and J. H. Prueger, "Managing soils to achieve greater water use efficiency," Agronomy Journal, vol. 93, no. 2, pp. 271-280, 2001.

[11] P. De, A. K. Chakravarti, P. K. Chakraborty, and A. Chakraborty, "Study on the efficacy of some bio resources as mulch for soil moisture conservation and yield of rain fed groundnut (Arachis hypogaea)," Archives of Agronomy and Soil Science, vol. 51, no. 3, pp. 247-252, 2005.

[12] J. S. Kang, A. Singh, and M. Kaur, "Studies on growth and yield of soybean (Glycine Max L. Merrill) under different planting methods and fertility levels," Legume Research, vol. 35, no. 3, pp. 265-267, 2012.

[13] A. Ajibola, T. Modupeola, and A. Adenuga, "Effect of different weed control practices on growth and yield of sesame in southwest Nigeria," Journal of Biological and Chemical Research, vol. 31, no. 2, pp. 1093-1100, 2014.

[14] M. B. Amoghein, A. T. Tobeh, A. Gholipouri, S. J. Somarin, and M. Ghasemi, "Effect of cover crop in control of weed density and 
some qualitative and quantitative characteristics of sunflower," International Journal of Agriculture and Crop Sciences, vol. 5, no. 12, p. 1318, 2013.

[15] Y.-M. Yang, X.-J. Liu, W.-Q. Li, and C.-Z. Li, "Effect of different mulch materials on winter wheat production in desalinized soil in Heilonggang region of North China," Journal of Zhejiang University: Science B (Biomedicine \& Biotechnology), vol. 7, no. 11, pp. 858-867, 2006.

[16] M. Schonbeck, "Mulching for weed management in organic vegetable production," eXtension, pp. 1-8, 2015, http://articles .extension.org/organic_production.

[17] W. L. Schrader, "Plasticulture in California Vegetable Production," University of California, Division of Agriculture and Natural Resources, pp. 1-9, 2000, http://anrcatalog.ucdavis.edu.

[18] R. W. Payne, D. A. Murray, S. A. Harding, D. B. Baird, and D. M. Soutar, An Introduction to GenStat for Windows, VSN International, Hemel Hempstead, UK, 12th edition, 2011, http:// vsni.co.uk/software/genstat.

[19] R Core Team., "R: A language and environment for statistical computing and graphics," The R Project for Statistical computing, Vienna, Austria, 2015, http://r-project.org.

[20] G. O. Nkansah, E. O. Owusu, K. O. Bonsu, and E. A. Dennis, "Effect of mulch type on the growth, yield and fruit quality of tomato (Lycopersicon esculentum Mill)," Ghana Journal of Horticulture, vol. 3, pp. 55-64, 2003.

[21] M. L. Pandita and N. Singh, "Vegetable production under water stress conditions in rainfed areas," in Adaptation of food crops to temperature and water stress. AVRDC, Shanhua, Taiwan, C. G. Kuo, Ed., pp. 467-472, 1992.

[22] W. J. Lamont, "The Use of Different Colored Mulches for Yield and Earliness," in Proceedings of the in proceedings of the New England Vegetable and Berry Growers Conference and Trade Show, pp. 299-302, Sturbridge, Mass, 1999.

[23] F. Vetrano, S. Fascella, G. Iapichino et al., "Response of melon genotypes to polyethylene and biodegradable starch-based mulching films used for fruit production in the Western Coast of Sicily," Acta Horticulturae, vol. 807, pp. 109-114, 2009.

[24] R. Agyare, R. Akromah, and M. Abdulai, "Assessment of Genetic Diversity in Pepper (Capsicum sp.) Landraces from Ghana Using Agro-morphological Characters," American Journal of Experimental Agriculture, vol. 12, no. 1, pp. 1-16, 2016. 


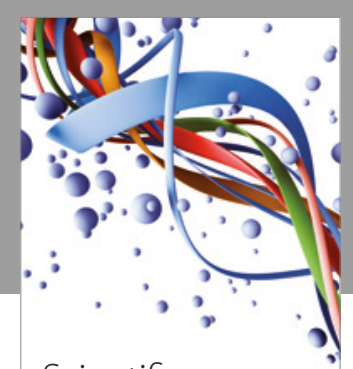

Scientifica
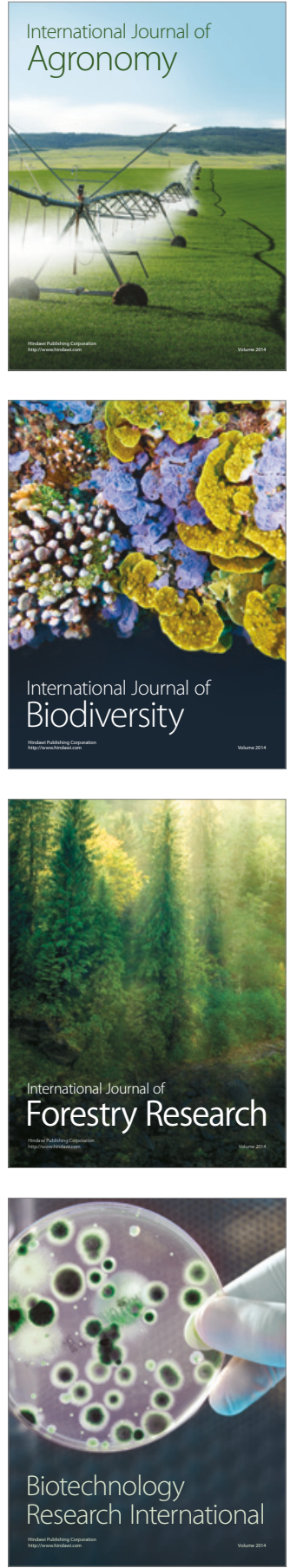
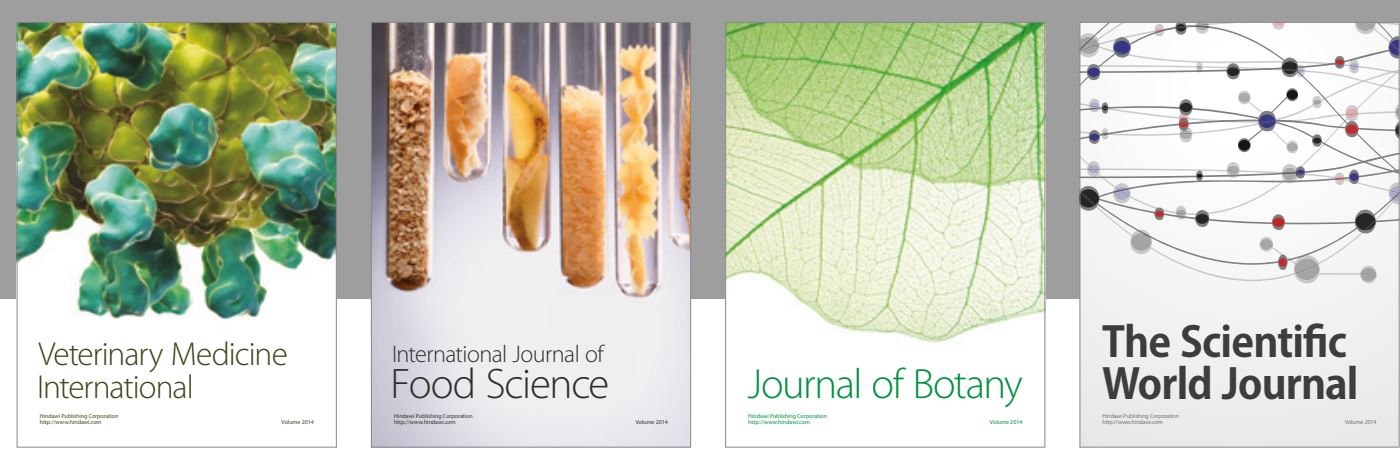

The Scientific

\section{World Journal}

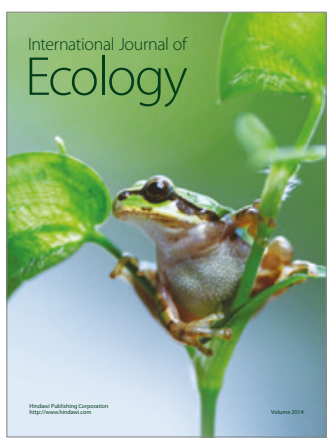

\section{Hindawi}

Submit your manuscripts at

https://www.hindawi.com
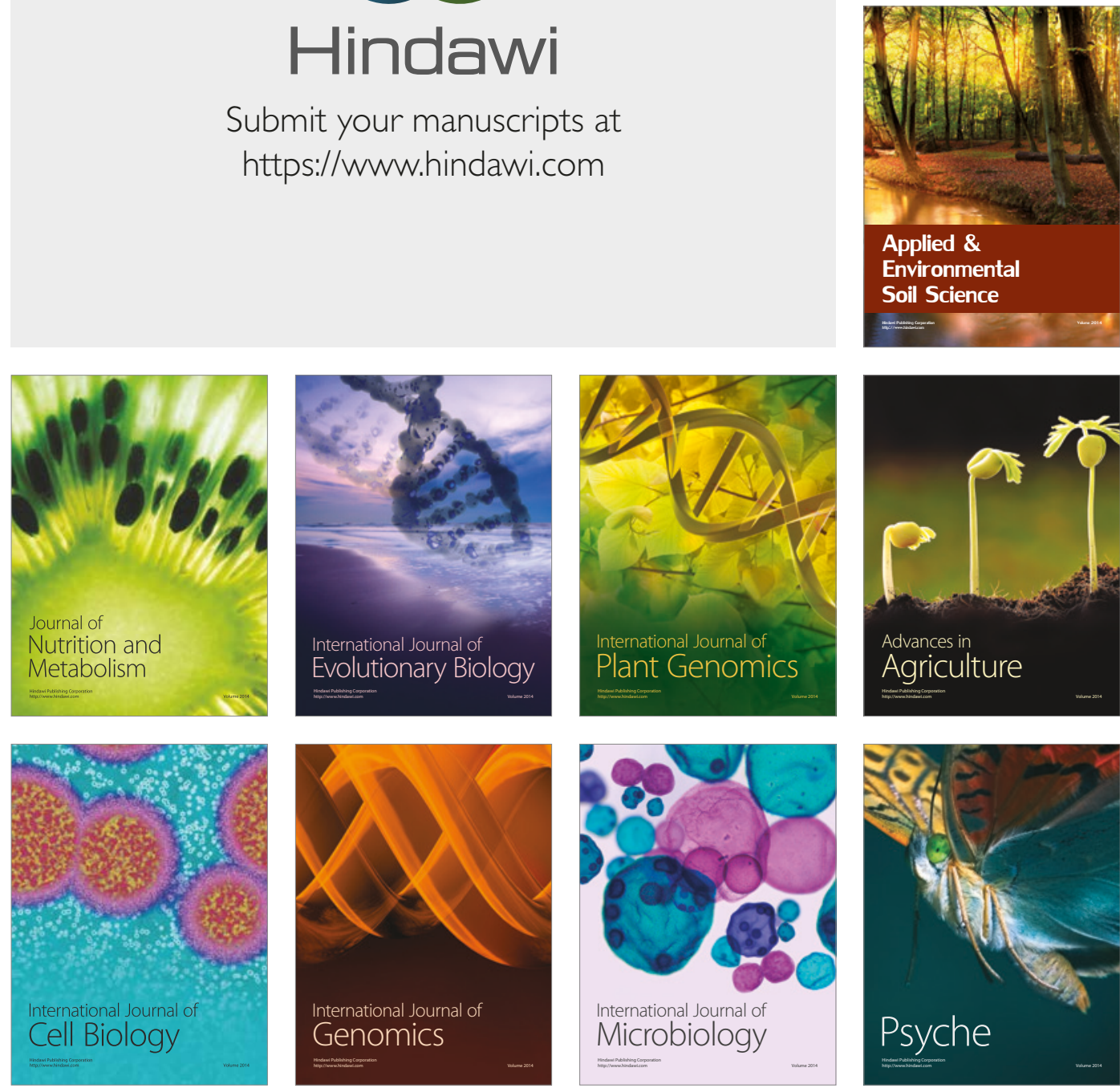

hternational Journal of Microbiology
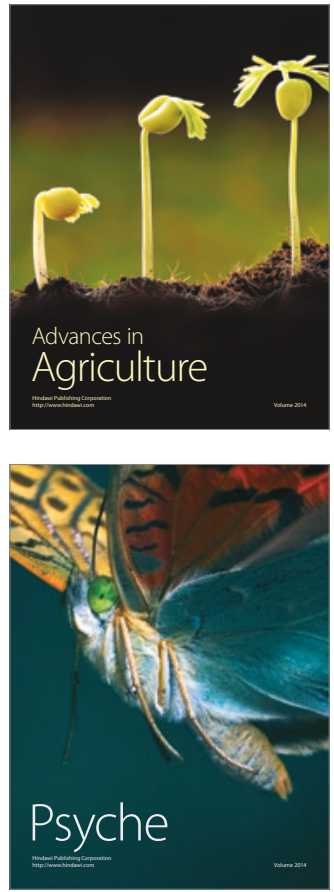